\title{
Antitumor agent yatein from Calocedrus formosana Florin leaf induces apoptosis in non-small-cell lung cancer cells
}

Shang-Tse Ho ${ }^{1,2}$, Chi-Chen Lin ${ }^{3}$, Tung-Lin Wu ${ }^{4}$, Yu-Tang Tung ${ }^{5,6,7^{*}}$ and Jyh-Horng Wu ${ }^{1 *}$ (D)

\begin{abstract}
Calocedrus formosana Florin is a softwood tree species with high economic value in Taiwan. Several bioactivities of the extracts of C. formosana have been reported; however, only one study focused on the anti-non-small-cell lung cancer cells' (anti-NSCLC) effect of C. formosana extract and its active phytocompound. In the present study, the anti-lung cancer effects of $C$. formosana leaf extract and its active derivative yatein were evaluated. The results revealed that the $n$-hexane fraction of the crude extract exhibited the highest cytotoxicity potential against two non-small-cell lung cancer (NSCLC) cell lines, namely A549 and CL1-5. Yatein, isolated from the $n$-hexane fraction, exhibited the highest cytotoxicity in the A549 and CL1-5 cells. In addition, the CL1-5 cells were more sensitive than the A549 cells after yatein treatment. Flow cytometry results revealed that yatein induced apoptosis in the two cell lines. Furthermore, expression of regulatory proteins related to apoptosis, such as caspase 3, caspase 8, caspase 9, and poly (ADP-ribose) polymerase (PARP), increased in the A549 and CL1-5 cells after yatein treatment. These findings provide insight into the in vitro anti-lung tumor efficacy of yatein, thus rendering this phytocompound a potential anticancer lead compound for NSCLC treatment.
\end{abstract}

Keywords: Apoptosis, Calocedrus formosana, Extracts, Lung cancer, Yatein

\section{Introduction}

Globally, lung cancer is the second most common cancer among men and women, and causes approximately 1.6 million deaths each year [1]. In 2012, up to $58 \%$ of lung cancer cases occurred in less developed [2]. Non-smallcell lung cancer (NSCLC), including lung squamous cell carcinoma, lung adenocarcinoma, and large cell lung cancer, accounts for more than $85 \%$ of lung cancer cases $[3,4]$. The major cause of lung cancer is tobacco smoking, and more than $80 \%$ of lung cancer cases in the United States are related to smoking [1]. Although lung squamous cell carcinoma is strongly associated with smoking, lung adenocarcinoma is the most common form of lung

\footnotetext{
*Correspondence: f91625059@tmu.edu.tw; eric@nchu.edu.tw

1 Department of Forestry, National Chung Hsing University, Taichung 402, Taiwan

${ }^{5}$ Graduate Institute of Metabolism and Obesity Sciences, Taipei Medical University, Taipei 110, Taiwan

Full list of author information is available at the end of the article
}

cancer that is observed in patients who never smoke [5] In addition to the high incidence rate, the 5-year survival rate of lung cancer is also lower than that of other common cancers [6]. Despite major advances in cancer therapeutics, efficient treatments to improve survival rates among patients with lung cancer are not currently available. Because of the therapeutic limitations of current conventional chemotherapeutic agents, the development of highly effective agents against lung cancer is necessary [7].

Recently, the cytotoxic effects of plant extracts have been widely studied $[8,9]$. Calocedrus formosana is a popular softwood tree species with a high economic value in craft and construction in Taiwan [10]. In addition to its high industrial value, studies have reported multiple bioactivities of the extract of $C$. formosana, including antimicrobial activity [11], antioxidant activity [12-14], cytotoxicity $[15,16]$, and immunoregulatory effects $[17$, 18]. Yuan et al. [16] demonstrated that $C$. formosana leaf 
extracts induce G2/M cell cycle arrest and apoptosis in human bladder cancer cells. In addition, Jayakumar et al. [19] reported that hinokitiol, a monoterpenoid isolated from C. formosana, inhibited the migration of A549 cells by suppressing the expression of matrix metalloproteinases. The finding implied that the $C$. formosana extract and its derived phytocompounds might be potential candidate therapeutic agents against lung cancer.

Previous studies are mainly focused on the anticancer potential of C. formosana extract alone or its major compound, hinokitiol $[16,19]$. To our knowledge, thus far, no previous study focused on the screening of NSCLC apoptosis inducers from C. formosana leaf extract through bioactivity-guided isolation strategy. Therefore, in the present study, the antitumor activities of $C$. formosana leaf extract and its active derivative yatein were assessed in human NSCLC A549 and CL1-5 cells, and the antitumor mechanisms of the active phytocompounds from $C$. formosana were examined.

\section{Materials and methods}

\section{Plant materials, extraction, and isolation}

C. formosana leaves were collected from the Hui-Sun experimental forest of National Chung Hsing University. The species was confirmed by Prof. Yen-Hsueh Tseng (Department of forestry, National Chung Hsing University). C. formosana leaves were soaked in methanol at room temperature twice for 1 week (each time) to obtain a methanolic extract. The filtered methanolic extract was concentrated and lyophilized using a rotary evaporator and freeze-drying equipment, respectively. The dried samples were divided to various soluble fractions, including $n$-hexane (yield $=14.8 \%$ ), ethyl acetate (EtOAc) (yield $=9.4 \%), n$-butanol $(n-\mathrm{BuOH})($ yield $=20.1 \%)$, and water (yield $=47.6 \%$ ) fractions, using liquid-liquid partition. After a cytotoxicity prescreening, the $n$-hexane fraction of $C$. formosana was further fractionated into 10 subfractions through column chromatography (Geduran Si-60, Merck, Darmstadt, Germany) using a gradient solvent system consisting of EtOAc and $n$-hexane. The cytotoxic phytocompound yatein was isolated and purified from subfraction 4 through semipreparative highperformance liquid chromatography (HPLC) using a PU-2080 pump (Jasco, Tokyo, Japan) equipped with an RI-2031 detector (Jasco) and a $5 \mu \mathrm{m}$ Luna silica column $(250 \times 10.0 \mathrm{~mm}$ internal diameter; Phenomenex, Torrance, CA, USA). The mobile phase consisted of $30 \%$ of EtOAc and $70 \%$ of $n$-hexane (v/v), and the flow rate was $4 \mathrm{ml} / \mathrm{min}$. The structure of yatein was identified using nuclear magnetic resonance imaging (Bruker Avance $400 \mathrm{MHz}$ FTNMR Spectrometer, Rheinstetten, Germany) and Finnigan MAT-95S ESIMS (San Jose, CA, USA), and all spectral data were consistent with the literature [20].
Additionally, yatein was quantified by HPLC with the same condition as aforementioned. For the calibration curve analysis, the yatein stock solution was dissolved in $30 / 70$ of $\mathrm{EtOAc} / n$-hexane $(\mathrm{v} / \mathrm{v})$, and then diluted to obtain the desired concentrations (200, 300,400,500, and $600 \mu \mathrm{g} / \mathrm{ml}$ ) for the quantification. The calibration curve was plotted using linear regression method (peak areas versus compound concentrations).

\section{Cell culture}

Human NSCLC A549 and CL1-5 cells were purchased from Bioresource Collection and Research Center (BCRC 60124) and provided by Dr. Jeremy J.-W. Chen (National Chung Hsing University, Taichung, Taiwan), respectively. A549 and CL1-5 cells were cultured in RPMI-1640 and Dulbecco's modified Eagle's medium (DMEM) medium (Gibco, Gran Island, NY, USA) supplemented with $10 \%$ $(\mathrm{v} / \mathrm{v})$ fetal bovine serum (Gibco) and a 1\% (v/v) antibiotic-antimycotic agent (Gibco). The cells were incubated in a $37^{\circ} \mathrm{C}$ humidified incubator containing $5 \% \mathrm{CO}_{2}$.

\section{Cell viability assay}

In this study, the 3-(4,5-dimethylthiazol-2-yl)-2,5-diphenyltetrazolium (MTT) (Sigma-Aldrich, St. Louis, MO, USA) test was used to evaluate cell viability. To measure the cytotoxicity of the extracts (test samples), the A549 and CL1-5 cells were seeded onto a 24-well plate $\left(1 \times 10^{4}\right.$ cells/well $)$ and incubated overnight. After overnight incubation, $1 \mathrm{ml}$ of fresh medium containing various concentrations of test samples [in $0.1 \%$ dimethyl sulfoxide (DMSO)] was added, and the cells were incubated at $37^{\circ} \mathrm{C}$ for various durations. The supernatant was removed after incubation and $200 \mu \mathrm{l}$ of MTT reagent ( $1 \mathrm{mg} / \mathrm{ml}$ in serum-free medium) was added. The cells were incubated for $3 \mathrm{~h}$ at $37^{\circ} \mathrm{C}$. The MTT reagent was removed and $600 \mu \mathrm{l}$ of DMSO was added to each well. The absorbance at $540 \mathrm{~nm}$ of each well was measured using a Tecan Sunrise ELISA reader (Tecan, Chapel Hill, NC).

\section{Annexin V-FITC binding assay}

The apoptotic patterns of lung cancer cells were determined using an Annexin V-FITC Apoptosis Detection Kit (BD Bioscience, San Jose, CA, USA). The treated cells were harvested, washed twice, and resuspended with $2 \mu \mathrm{l}$ of Annexin V-FITC and $2 \mu \mathrm{l}$ of propidium iodide (PI) (BD Bioscience) in $100 \mu \mathrm{l}$ of binding buffer (0.01 M HEPES, $\mathrm{pH} 7.4 ; 0.14 \mathrm{M} \mathrm{NaCl} ; 2.5 \mathrm{mM} \mathrm{CaCl}_{2}$ ) (BD Bioscience) for $15 \mathrm{~min}$ at room temperature in the dark. The cells were immediately analyzed using flow cytometry (Accuri 5, Accuri Cytometers, Ann Arbor, MI, USA). 


\section{Western blot analysis}

The expression levels of proteins in the cells were determined through Western blot analysis as previously reported [8]. In this study, the primary antibodies were anti- $\beta$-actin (Santa Cruz, Dallas, TX, USA), anti-cleaved caspase 3 (Cell Signaling Technology, Danvers, MA, USA), anti-cleaved caspase 8 (Cell Signaling Technology), anti-cleaved caspase 9 (Cell Signaling Technology), and anti-cleaved PARP (Cell Signaling Technology). An enhanced chemiluminescence (ECL) (Sigma-Aldrich) system was used for developing signals of the blots, which were analyzed using an LAS3000 system (Fujifilm, Tokyo, Japan). The experiments were at least duplicate.

\section{Reactive oxygen species (ROS) assay}

A549 and CL1-5 cells were seeded onto a 6-well plate $\left(1 \times 10^{5}\right.$ cells/well). After overnight incubation, cells were treated with $5 \mu \mathrm{M}$ of yatein for $1,3,6$, and $12 \mathrm{~h}$. At each time point, the cells were harvested, centrifuged, and stained with $5 \mu \mathrm{M}$ of $2^{\prime}, 7^{\prime}$-dichlorofluorescin diacetate (DCFH-DA) for $10 \mathrm{~min}$ at $4{ }^{\circ} \mathrm{C}$. The ROS production levels were measured as FL-1 fluorescence intensity by flow cytometer (BD Biosciences).

\section{Statistical analysis}

Data are expressed as mean \pm standard deviation (SD). Statistical analysis was performed using the shuffle test or Student's $t$ test. A value of $p<0.05$ was considered statistically significant.

\section{Results}

Cytotoxicity of C. formosana leaf extract in human NSCLC A549 and CL1-5 cells

To evaluate the cytotoxic potential of C. formosana leaf extract in human NSCLC cells, the cell viability of A549 and CL1-5 cells after treatment with a methanolic extract of $C$. formosana leaf and its derived soluble fractions ( $n$-hexane, EtOAc, $n$-BuOH, and water fraction) for $24 \mathrm{~h}$ were determined using the MTT assay. The results revealed that at $5 \mu \mathrm{g} / \mathrm{ml}$, the $n$-hexane and EtOAc fractions exhibited higher cytotoxicity levels in the A549 and CL1-5 cells than the other fractions (Fig. 1a). As shown in Fig. $1 \mathrm{~b}$ and c, both the $n$-hexane and EtOAc fractions exhibited cytotoxic effects on the human NSCLC cells; the half maximal inhibitory concentration $\left(\mathrm{IC}_{50}\right)$ values of the $n$-hexane fraction in the A549 and CL1-5 cells were 23.1 and $1.2 \mu \mathrm{g} / \mathrm{ml}$, respectively. The cytotoxic effects of the $n$-hexane and EtOAc fractions were comparable; however, the yield of $n$-hexane fraction $(14.8 \%)$ was higher than that of the EtOAc fraction (9.4\%). Therefore,
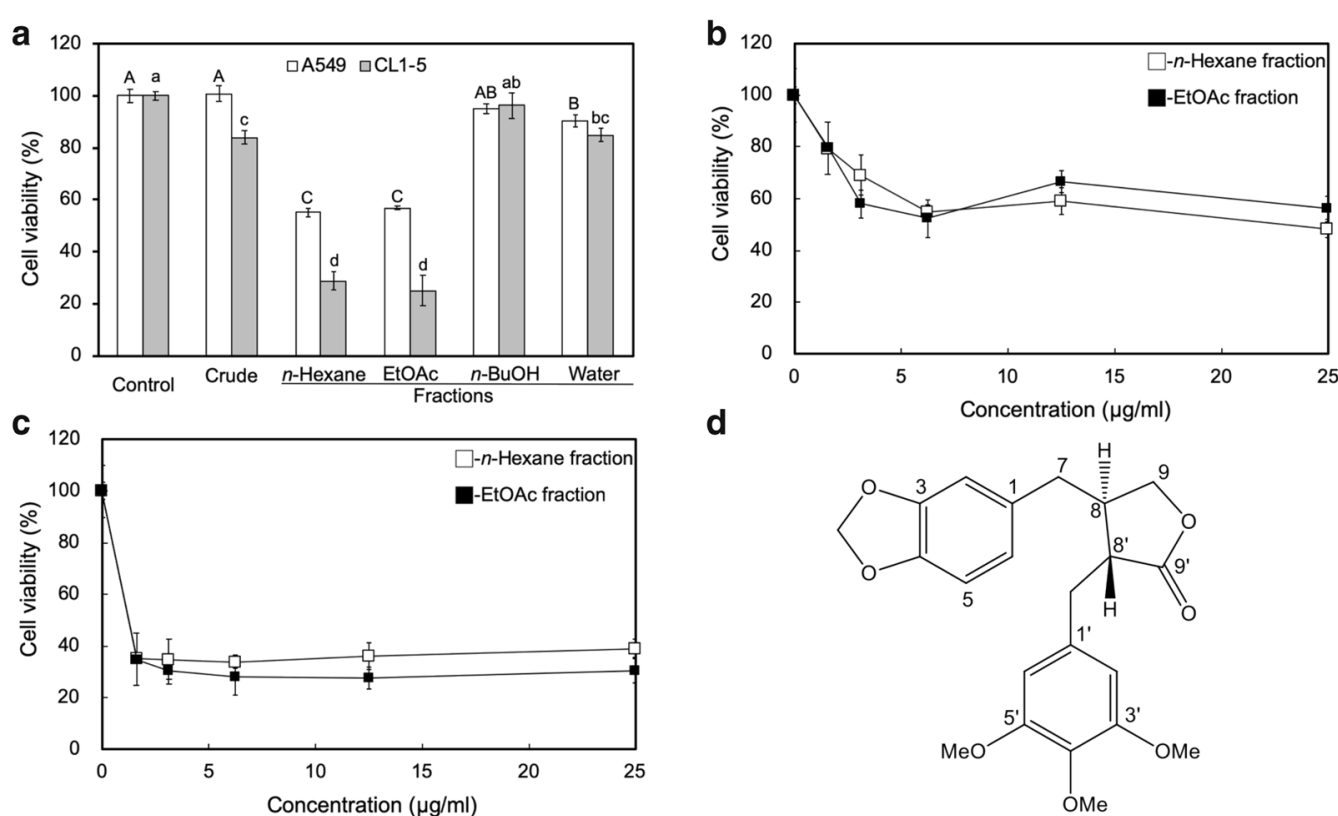

d

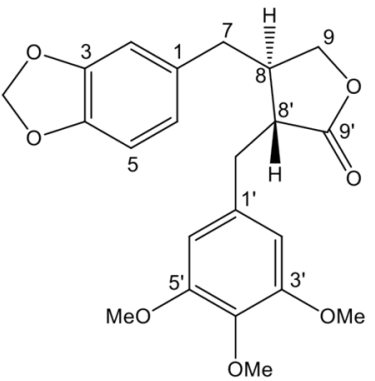

Fig. 1 Cytotoxic effect of Calocedrus formosana leaf extract. a Cell viability of A549 and CL 1-5 cells after treatment for $24 \mathrm{~h} \mathrm{with} 5 \mu \mathrm{g} / \mathrm{ml}$ of methanolic extract and the derived soluble fractions. Cell viability of the $\mathbf{b}$ A549 and c CL1-5 cells after treatment with the $n$-hexane and EtOAc fractions of C. formosana leaf extract for $24 \mathrm{~h}$. $\mathbf{d}$ The structure of yatein. The results represent the mean \pm SD $(n=3)$. Different capital and lowercase letters indicate significant differences among each group in the A549 and CL1-5 cells, respectively $(p<0.05)$. $p$ values were calculated by one-way ANOVA, followed by shuffle test 
Table 1 The weight fraction and cytotoxicity of $\boldsymbol{n}$-hexane soluble subfractions from the leaf of $C$. formosana

\begin{tabular}{llll}
\hline Subfractions & $\begin{array}{l}\text { Mobile phase } \\
(\mathbf{v} / \mathbf{v})\end{array}$ & $\begin{array}{l}\text { Weight } \\
\text { fraction (\%) }\end{array}$ & Cell viability (\%) \\
\hline 1 & $5 / 95^{\mathrm{b}}$ & 50.4 & $67.4 \pm 15.2$ \\
2 & $10 / 90^{\mathrm{b}}$ & 11.1 & $>80$ \\
3 & $20 / 80^{\mathrm{b}}$ & 3.4 & $>80$ \\
4 & $20 / 80^{\mathrm{b}}$ & 7.0 & $43.3 \pm 2.6$ \\
5 & $30 / 70^{\mathrm{b}}$ & 2.8 & $>80$ \\
6 & $50 / 50^{\mathrm{b}}$ & 2.4 & $>80$ \\
7 & $70 / 30^{\mathrm{b}}$ & 0.6 & $>80$ \\
8 & $100 / 0^{\mathrm{b}}$ & 1.1 & $>80$ \\
9 & $10 / 90^{\mathrm{C}}$ & 9.4 & $>80$ \\
10 & $30 / 70^{\mathrm{C}}$ & 11.8 & $>80$ \\
\hline
\end{tabular}

${ }^{a}$ Cell viability of A549 cells after treatment with $10 \mu \mathrm{g} / \mathrm{ml}$ of each subfraction for $24 \mathrm{~h}$

${ }^{b}$ EtOAc/n-hexane

c $\mathrm{MeOH} / \mathrm{EtOAc}$

the active phytocompounds were further isolated, purified, and identified from the $n$-hexane fraction. The $n$-hexane fraction was fractionated into ten subfractions through column chromatography (Si-60 gel). The results of the cytotoxicity screening of the subfractions revealed that subfraction 4 exhibited the highest growth inhibition in the A549 cells (Table 1). Based on the aforementioned results, the bioactivity-guided isolation principle was applied in this study, and the bioactive phytocompound of subfraction 4 is yatein (Fig. 1d) which was isolated and purified through HPLC using a normal phase system (Additional file 1: Fig. S1a). The yield of yatein was $11.1 \pm 0.2 \mu \mathrm{g} / \mathrm{g}$ of dry leave sample based on the calibration curve $\left(R^{2}=0.9963\right.$, Additional file 1: Fig. S1b). In addition, the purity of yatein was estimated higher than 95\% according to the ${ }^{1} \mathrm{H}$ NMR results (Additional file 1: Fig. S1c).

\section{Yatein induces cytotoxic effect in human NSCLC A549 and $\mathrm{CL} 1-5$ cells}

The viabilities of the A549 and CL1-5 cells after treatment with various concentrations of yatein for 24, 48, 72 , and $96 \mathrm{~h}$ are shown in Fig. 2a and b, respectively. The results revealed that yatein exhibited high cytotoxicity in the A549 and CL1-5 cells, and the $\mathrm{IC}_{50}$ values of yatein in the A549 and CL1-5 cells were 3.5 and $1.9 \mu \mathrm{M}$ after treatment for $72 \mathrm{~h}$. The results revealed that yatein was a natural cytotoxic agent that strongly inhibited NSCLC cell growth. Therefore, the mechanism underlying the growth inhibitory effect of yatein in the A549 and CL1-5 cells was further investigated in the present study.
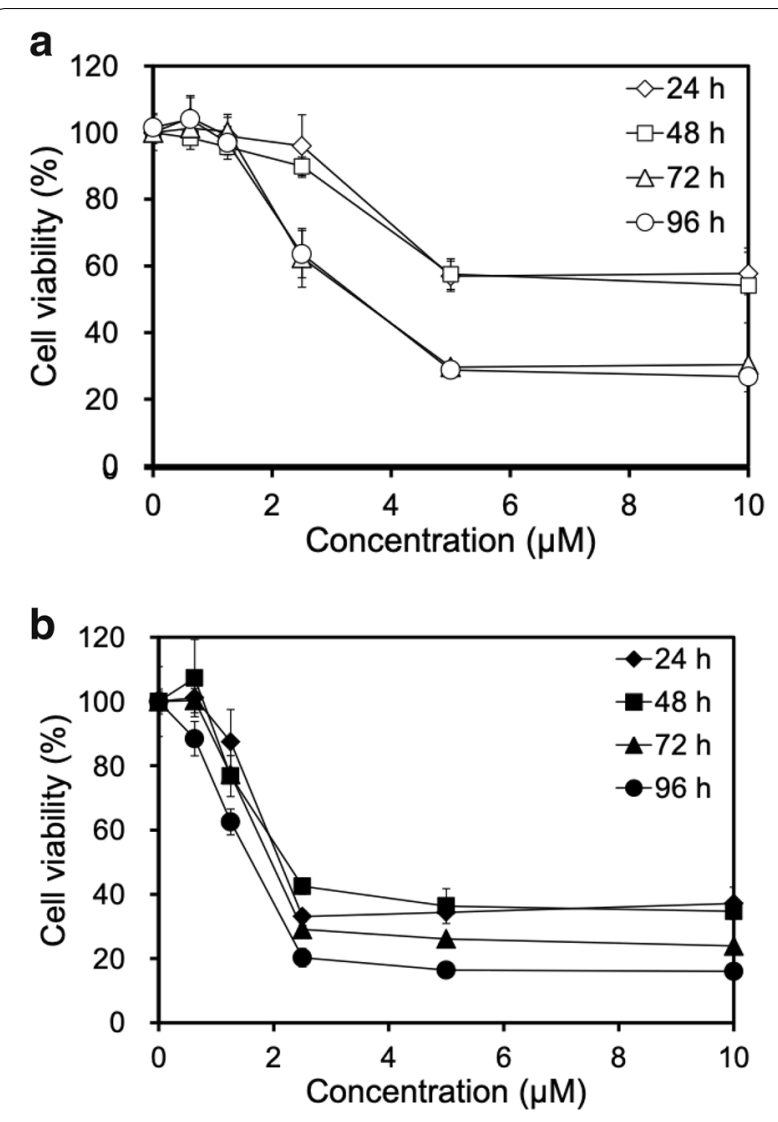

Fig. 2 Cell viability of the $\mathbf{a}$ A549 and $\mathbf{b}$ CL 1-5 cells after treatment with various concentrations of yatein for 24-96 h. The results represent the mean $\pm \mathrm{SD}(n=3)$

Yatein induces apoptosis by enhancing apoptosis-related protein expressions and ROS production in the A549 and CL1-5 cells

Additionally, we determined whether yatein inhibited the growth of the A549 and CL1-5 cells by inducing apoptosis in these two types of cells. To evaluate the apoptosis features of the A549 and CL1-5 cells, the yatein-treated cells were stained using the Annexin V/PI reagents and then analyzed using a flow cytometer. The results indicated that the population in the early apoptosis stage of CL1-5 cells increased in a dose-dependent manner after yatein treatment for $24 \mathrm{~h}$. As shown in Fig. 3, 15.1\% of early apoptotic cells and $8.9 \%$ of late apoptotic CL1-5 cells were observed after $5 \mu \mathrm{M}$ yatein treatment for $24 \mathrm{~h}$. By contrast, the A549 cells exhibited a different trend in the apoptosis stages compared with the CL1-5 cells after yatein treatment for $24 \mathrm{~h}$, both of early and late apoptotic cells were less than $5 \%$. After treatment with yatein for $48 \mathrm{~h}$, the populations of the A549 and CL1-5 cells in the early and late apoptosis stages exhibited a dosedependent increase (Fig. 3). The aforementioned findings 
A549

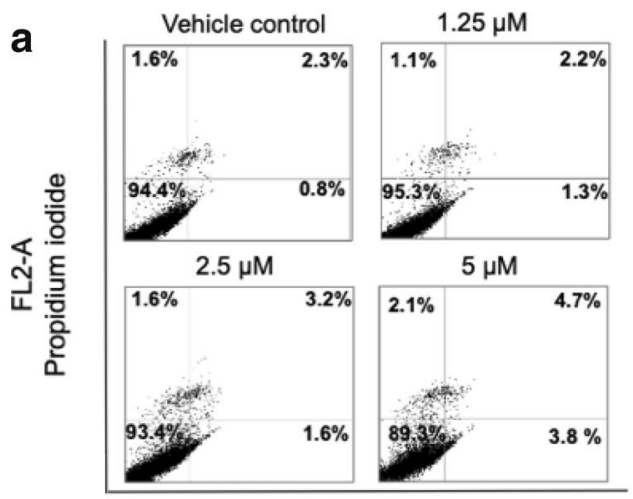

FL1-A

Annexin V

A549

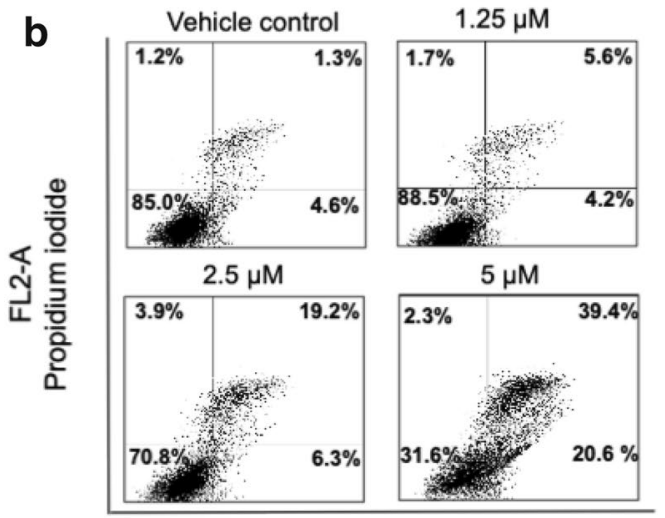

FL1-A

Annexin V

\section{CL1-5}

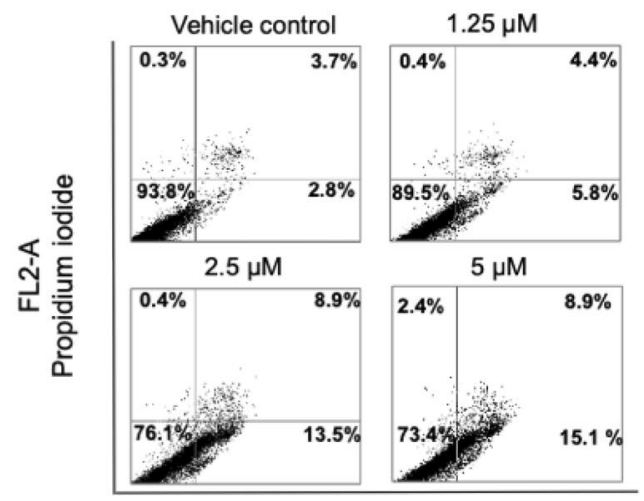

FL1-A

Annexin V

\section{CL1-5}

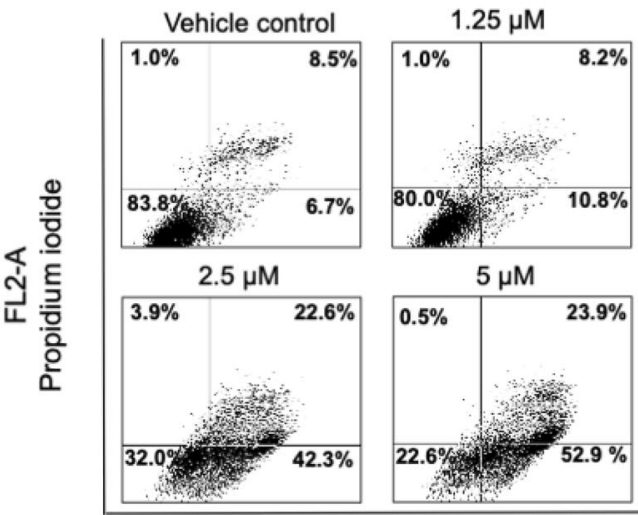

FL1-A

Annexin V

Fig. 3 Annexin V/PI staining of the A549 and CL1-5 cells after yatein treatment for $\mathbf{a} 24$ and $\mathbf{b} 48 \mathrm{~h}$. The results represent the mean $(n=3)$

indicate that yatein might have induced apoptosis in these two types of cells for 24 and $48 \mathrm{~h}$ treatment.

The expression of apoptosis-related proteins, including cleaved PARP and cleaved caspases 9, 8, and 3, was analyzed after the A549 and CL1-5 cells treated with $5 \mu \mathrm{M}$ yatein for $0,12,24$, and $48 \mathrm{~h}$. As shown in Figs. 4 and 5 , the activation of cleaved PARP and cleaved caspase 3, 8 , and 9 increased in these two cell lines after yatein treatment for $48 \mathrm{~h}$. The results implied that yatein induced caspase pathway activation and apoptosis in the A549 and CL1-5 cells. In addition, as shown in Fig. 6, yatein induced ROS formation in the NSCLC cells at various time points in these two cell lines. Accordingly, we found that the CL1-5 cells were more sensitive for the ROS production than the A549 cells after yatein treatment.

\section{Discussion}

The present study demonstrated for the first time the in vitro anti-NSCLC effects of C. formosana leaf extract and its active derivative yatein. Our results indicated that the $C$. formosana leaf extracts exhibited high cytotoxicity $\left(\mathrm{IC}_{50}\right.$ values of the $n$-hexane fraction in the A549 and CL1-5 cells were 23.1 and $1.2 \mu \mathrm{g} / \mathrm{ml}$, 


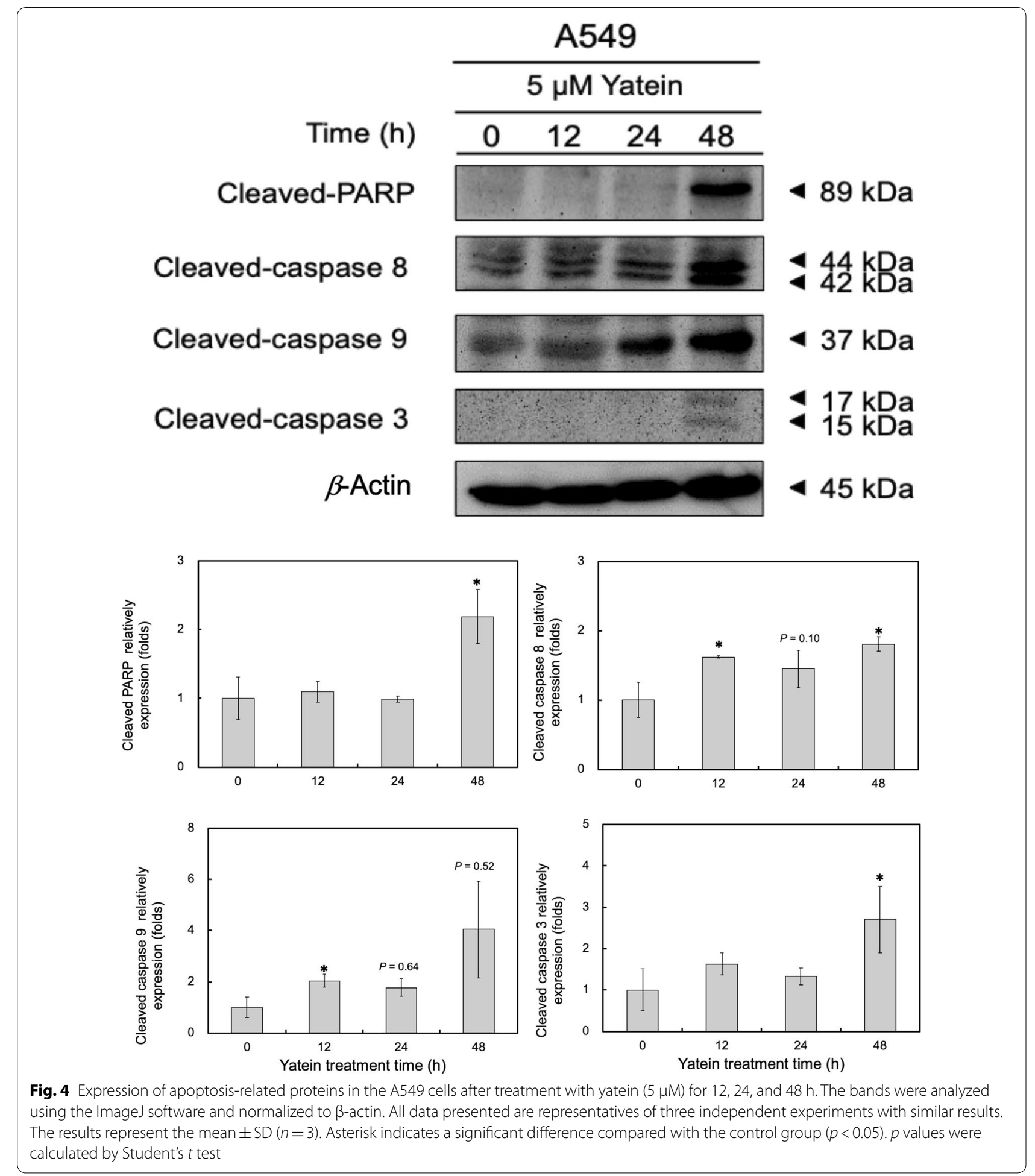

respectively) in the A549 and CL1-5 cells. We compared the cytotoxic effects of the $C$. formosana leaf extract with those of potential anti-NSCLC plant extracts, such as Punica granatum ( $\mathrm{IC}_{50}$ value of $\mathrm{A} 549$ cells $>150 \mu \mathrm{g} / \mathrm{ml})$, Brachylaena ramiflora $\left(\mathrm{IC}_{50}\right.$ value of A549 cells $=20 \mu \mathrm{g} / \mathrm{ml})$, Vernonia garnieriana $\left(\mathrm{IC}_{50}\right.$ value of A549 cells $=79 \mu \mathrm{g} / \mathrm{ml})$, Flacourtia indica $\left(\mathrm{IC}_{50}\right.$ value of A549 cells $=100 \mu \mathrm{g} / \mathrm{ml}$ ), and Rhododendron 


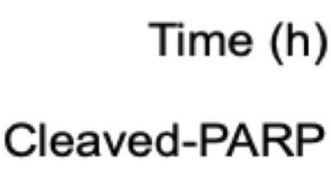

Cleaved-caspase 8

Cleaved-caspase 9

Cleaved-caspase 3

$\beta$-Actin

\section{CL1-5 \\ $5 \mu \mathrm{M}$ Yatein}

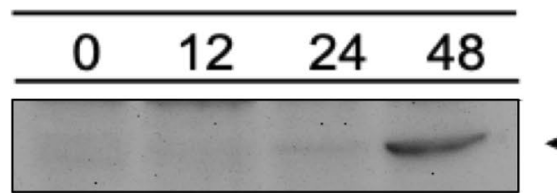

$89 \mathrm{kDa}$

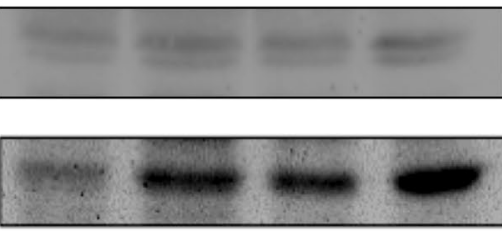

$44 \mathrm{kDa}$

$37 \mathrm{kDa}$

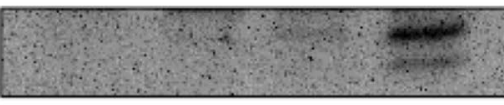

$17 \mathrm{kDa}$

$15 \mathrm{kDa}$

$45 \mathrm{kDa}$
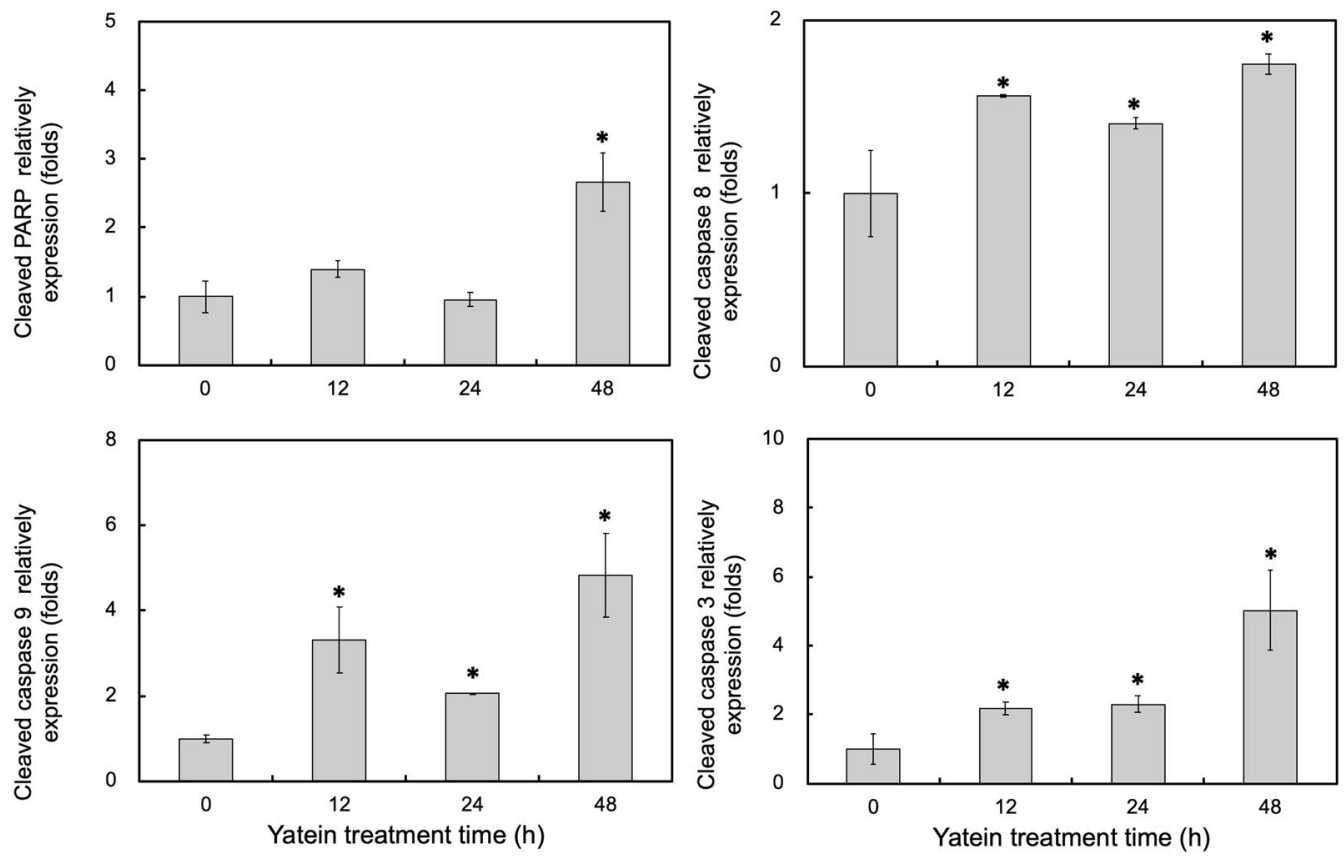

Fig. 5 Expression of apoptosis-related proteins in the CL1-5 cells after treatment with yatein ( $5 \mu \mathrm{M})$ for 12, 24, and $48 \mathrm{~h}$. The bands were analyzed using the ImageJ software and normalized to $\beta$-actin. All data presented are representatives of three independent experiments with similar results. The results represent the mean $\pm \mathrm{SD}(n=3)$. Asterisk indicates a significant difference compared with the control group $(p<0.05)$. $p$ values were calculated by Student's $t$ test

formosanum $\left(\mathrm{IC}_{50}\right.$ value of $\mathrm{A} 549$ cells $\left.=80 \mu \mathrm{g} / \mathrm{ml}\right)$ [21-23]; the cytotoxic potential of the C. formosana leaf extract was higher than that of the aforementioned extracts. On the other hand, C. formosana leaf extracts also possessed cytotoxicity against bladder cancer cell growth $\left(\mathrm{IC}_{50}\right.$ value $\cong 10 \mu \mathrm{g} / \mathrm{ml}$ for TCCSUP, T24, and TSGH-8301 cells after treatment for $48 \mathrm{~h}$ ) [16], suggesting that C. formosana leaf extracts may exhibit broadspectrum cytotoxicity against various cancer cells. 


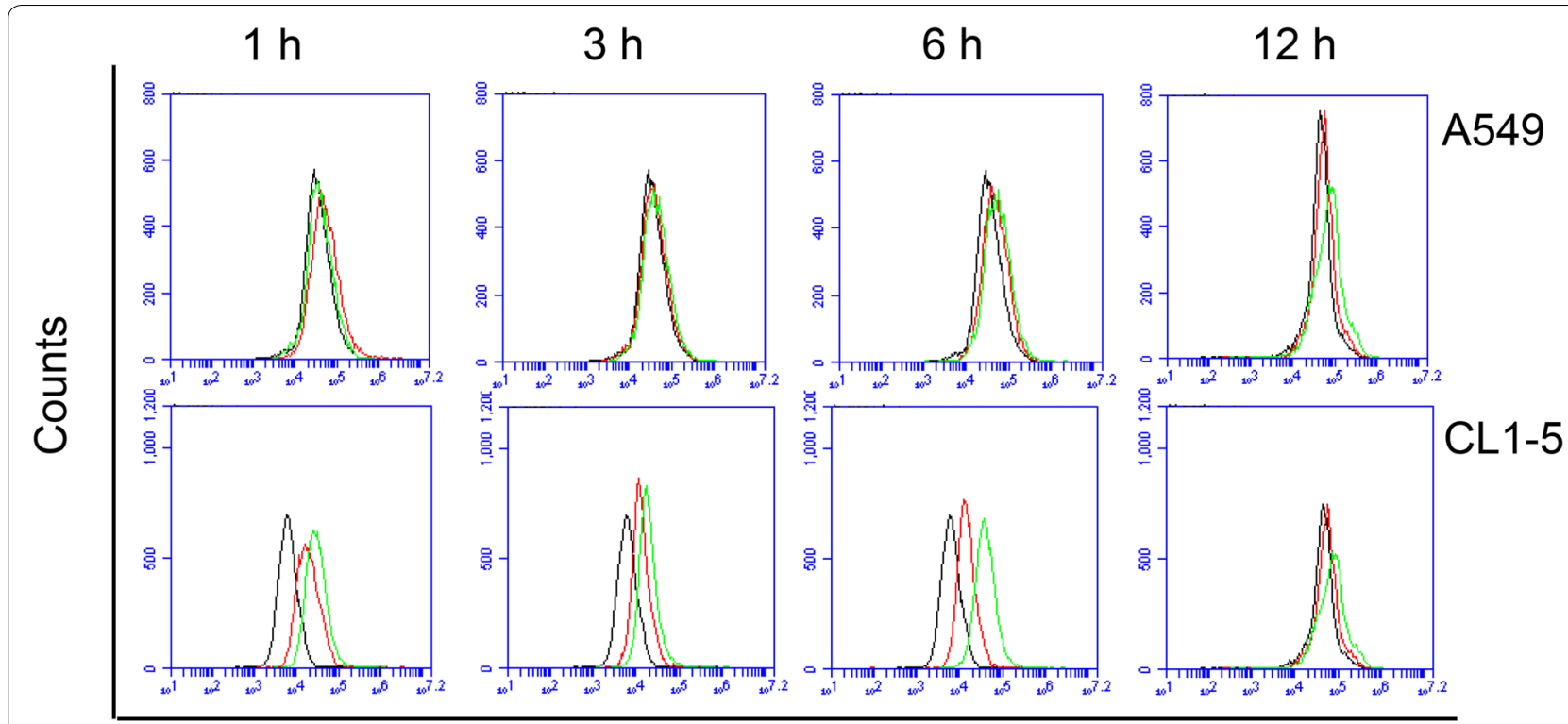

FL1-A

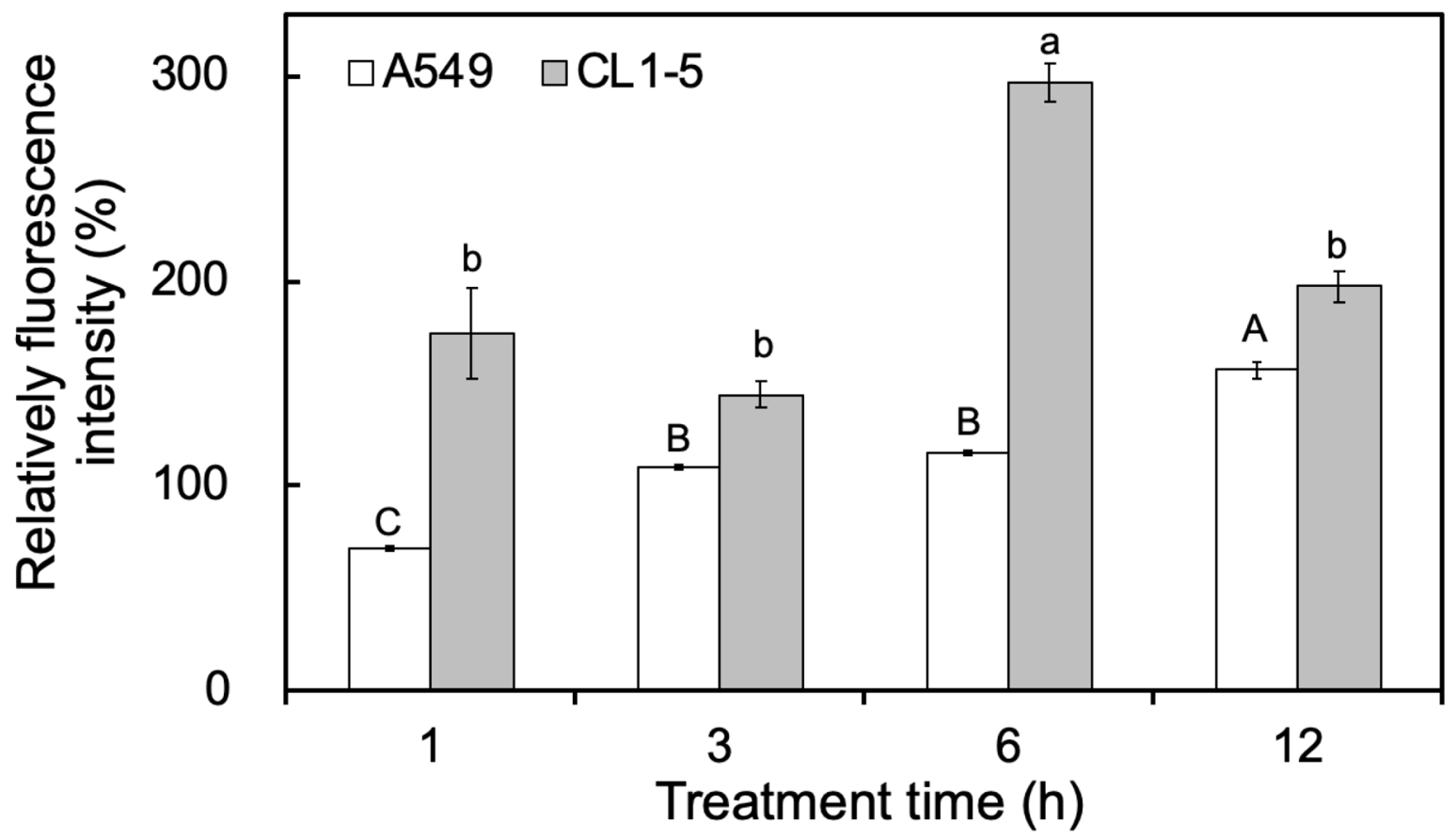

Fig. 6 ROS levels of A549 and CL1-5 cells after treatment with $5 \mu$ M yatein for 1, 3, 6, and 12 h. Black line: unstained cells, red line: control group, and green line: yatein treatment group. The results represent the mean $\pm S D(n=3)$; different capital and lowercase letters indicate significant differences among each group in the A549 and CL1-5 cells, respectively $(p<0.05)$. $p$ values were calculated by one-way ANOVA, followed by shuffle test 
As previously reported, some phytocompounds from C. formosana leaf extracts were able to inhibit cancer cell growth; for instance, hinokitiol inhibited A549 cell growth at a high dosage (more than $20 \mu \mathrm{M}$ ) [19]. Additionally, we found that yatein exerted a stronger inhibitory effect on the growth of the A549 cells ( $\mathrm{IC}_{50}$ value $=3.5 \mu \mathrm{M}$ after treatment for $72 \mathrm{~h}$ ) than did other lignans that have been reported to have anti-NSCLC growth effects in previous studies. The inhibitory effects of lignan compounds on NSCLC have been reported in previous studies. For example, Min et al. isolated several lignans from Schisandra chinensis [24]. Among these phytochemicals, schisantherin $C$ exhibited the highest inhibitory effects on the A549 cell growth with an $\mathrm{IC}_{50}$ value of $5.6 \mu \mathrm{M}$, followed by schizandrin $(20.7 \mu \mathrm{M})$ and gomisin $\mathrm{N}(21.1 \mu \mathrm{M})$. A lignan isolated from Endiandra anthropophagorum, (-)-dihydroguaiaretic acid, has been reported to have growth inhibitory effects on $\mathrm{A} 549$ cells with an $\mathrm{IC}_{50}$ value of $7.5 \mu \mathrm{M}$ [25]. Furthermore, Ou et al. [26] reported that $Z$-isochaihulactone (a lignan isolated from Bupleurum scorzonerifolium) displayed cytotoxicity in A549 cells $\left(\mathrm{IC}_{50}\right.$ value $\left.=7.5 \mu \mathrm{M}\right)$. Based on the aforementioned reports, lignan compounds have notable potential as new cytotoxic lead compounds for treatment of NSCLC.

To evaluate the anti-NSCLC growth mechanism of yatein, the regulatory effect of yatein on the apoptosisrelated pathway was determined using flow cytometry and Western blot analysis. The result of Western blot analysis was consistent with the results of Annexin V/ PI staining; we found that prolonged yatein treatment was associated with an increase in apoptosis features in the cells, as observed through flow cytometry and Western blot analysis. Caspase family proteins play a vital role during the apoptotic process; the activated caspase proteins are able to trigger the programed cell death. Our finding indicated that yatein induced caspase-dependent apoptosis and activated intrinsic and extrinsic apoptotic pathways in the A549 and CL1-5 cells by activating expression of caspase 8 and caspase 9 and then inducing caspase 3 and PARP protein activation. Additionally, yatein induced ROS formation in the NSCLC cells at various time points. ROS has multiple functions in cell biology. At proper doses, ROS are able to regulate cell development functions, including cell cycle regulation, cell death, differentiation, migration, and proliferation. However, excess ROS production would cause severe damage to biomolecules, and then induced apoptosis and/or necrosis [27-29]. Additionally, previous studies also showed that lignan compounds are able to induce apoptosis through producing ROS in various cell types [30-34]. Thus, based on aforementioned, we speculated that ROS formation was involved in yatein-mediated cell death.

\section{Conclusions}

The present study demonstrated that C. formosana Florin leaf extract and its active phytocompound, yatein, suppressed NSCLC growth through the induction of apoptosis. According to the results from flow cytometry and Western blot analyses, we found that yatein initialized the apoptosis cascade in the intrinsic and extrinsic signaling pathways. Additionally, ROS production was also involved in the mechanism underlying yatein-mediated NSCLC growth inhibition. These findings provide insight into the in vitro anti-lung tumor efficacy of yatein, thus rendering this phytocompound a potential anticancer lead compound for NSCLC treatment. However, the in vivo anti-lung tumor effects of yatein are still needed for the future study.

\section{Supplementary information}

Supplementary information accompanies this paper at https://doi. org/10.1186/s10086-019-1838-9.

Additional file 1: Fig. S1. HPLC chromatogram of subfraction 4 from $n$-hexane fraction of C. formosana leaf extract (a), calibration curve of yatein quantification (b), and ${ }^{1} \mathrm{H}$ NMR spectrum $\left(\mathrm{CDCl}_{3}, 400 \mathrm{MHz}\right)$ of yatein (c).

\section{Abbreviations}

BuOH: n-butanol; BSA: bovine serum albumin; C. formosana: Calocedrus formosana; DMEM: Dulbecco's modified Eagle's medium; DMSO: dimethyl sulfoxide; ECL: enhanced chemiluminescence; EtOAc: ethyl acetate; MTT: 3-(4,5-dimethylthiazol-2-yl)-2,5-diphenyltetrazolium; NSCLC: non-small-cell lung cancer; PARP: poly (ADP-ribose) polymerase; PBS: phosphate-buffered saline; PI: propidium iodide; ROS: reactive oxygen species; SD: standard deviation.

\section{Authors' contributions}

J-HW and C-CL designed the experiments; S-TH, T-LW, and Y-TT performed the experiments. C-CL, Y-TT, and J-HW supported reagents and kits. S-TH, Y-TT, and J-HW analyzed the data and wrote the manuscript. All authors read and approved the final manuscript.

\section{Funding}

This research work was supported in part by the Ministry of Science and Technology of Taiwan and Taipei Medical University under Grant Nos. MOST 107-2628-H-038-001-MY3 and 106-6820-001-112, respectively.

\section{Availability of data and materials}

All data generated or analyzed during this study are included in this published article and its supplementary information files.

\section{Competing interests}

The author(s) declared no potential competing interest with respect to the research, authorship, and/or publication of this article.

\section{Author details}

${ }^{1}$ Department of Forestry, National Chung Hsing University, Taichung 402, Taiwan. ${ }^{2}$ Agricultural Biotechnology Research Center, Academia Sinica, Taipei 115 , Taiwan. ${ }^{3}$ Institute of Biomedical Science, National Chung Hsing University, Taichung 402, Taiwan. ${ }^{4}$ College of Technology and Master of Science 
in Computer Science, University of North America, Fairfax, VA 22033, USA ${ }^{5}$ Graduate Institute of Metabolism and Obesity Sciences, Taipei Medical University, Taipei 110, Taiwan. ${ }^{6}$ Nutrition Research Center, Taipei Medical University Hospital, Taipei 110, Taiwan. ${ }^{7}$ Cell Physiology and Molecular Image Research Center, Wan Fang Hospital, Taipei Medical University, Taipei 116, Taiwan.

Received: 28 May 2019 Accepted: 16 October 2019

Published online: 31 October 2019

\section{References}

1. Herbst RS, Morgensztern D, Boshoff C (2018) The biology and management of non-small cell lung cancer. Nature 553:446

2. Ferlay J, Soerjomataram I, Dikshit R, Eser S, Mathers C, Rebelo M, Parkin DM, Forman D, Bray F (2015) Cancer incidence and mortality worldwide: sources, methods and major patterns in GLOBOCAN 2012. Int J Cancer 136:E359-E386

3. Molina JR, Yang P, Cassivi SD, Schild SE, Adjei AA (2008) Non-small cell lung cancer: epidemiology, risk factors, treatment, and survivorship. Mayo Clin Proc 83:584-594

4. Pao W, Girard N (2011) New driver mutations in non-small-cell lung cancer. Lancet Oncol 12:175-180

5. Sun S, Schiller JH, Gazdar AF (2007) Lung cancer in never smokers-a different disease. Nat Rev Cancer 7:778-790

6. Wong MCS, Lao XQ, Ho K-F, Goggins WB, Tse SLA (2017) Incidence and mortality of lung cancer: global trends and association with socioeconomic status. Sci Rep 7:14300

7. Denisenko TV, Budkevich IN, Zhivotovsky B (2018) Cell death-based treatment of lung adenocarcinoma. Cell Death Dis 9:117

8. Ho ST, Tung YT, Kuo YH, Lin CC, Wu JH (2015) Ferruginol inhibits non-small cell lung cancer growth by inducing caspase-associated apoptosis. Integr Cancer Ther 14:86-97

9. Chang ST, Wang SY, Kuo YH (2003) Resources and bioactive substances from Taiwania (Taiwania cryptomerioides). J Wood Sci 49:1-4

10. Chen YJ, Cheng SS, Chang ST (2009) Monitoring the emission of volatile organic compounds from the leaves of Calocedrus macrolepis var. formosana using solid-phase micro-extraction. J Wood Sci 56:140-147

11. Yen TB, Chang HT, Hsieh CC, Chang ST (2008) Antifungal properties of ethanolic extract and its active compounds from Calocedrus macrolepis var. formosana (Florin) heartwood. Bioresour Technol 99:4871-4877

12. Ho CL, Tseng YH, Wang El, Liao PC, Chou JC, Lin CN, Su YC (2011) Composition, antioxidant and antimicrobial activities of the seed essential oil of Calocedrus formosana from Taiwan. Nat Prod Commun 6:133-136

13. Wang SY, Wu JH, Cheng SS, Lo CP, Chang HN, Shyur LF, Chang ST (2004) Antioxidant activity of extracts from Calocedrus formosana leaf, bark, and heartwood. J Wood Sci 50:422-426

14. Yen PL, Wu CL, Chang ST, Huang SL, Chang HT (2012) Antioxidative lignans from phytochemical extract of Calocedrus formosana Florin BioResources 7:4122-4131

15. Chiang YM, Liu HK, Lo JM, Chien SC, Chan YF, Lee TH, Su JK, Kuo YH (2013) Cytotoxic constituents of the leaves of Calocedrus formosana. J Chin Chem Soc 50:161-166

16. Yuan SY, Lin CC, Hsu SL, Cheng YW, Wu JH, Cheng CL, Yang CR (2011) Leaf extracts of Calocedrus formosana (Florin) induce G2/M cell cycle arrest and apoptosis in human bladder cancer cells. Evid-based Compl Alt 2011:380923

17. Tsai CC, Chen CJ, Tseng HW, Hua KF, Tsai RY, Lai MH, Chao LK, Chen ST (2008) Cytomic screening of immuno-modulating activity compounds from Calocedrus formosana. Comb Chem High T Scr 11:834-842

18. Chao KP, Hua KF, Hsu HY, Su YC, Chang ST (2005) Anti-inflammatory activity of sugiol, a diterpene isolated from Calocedrus formosana bark. Planta Med 71:300-305
19. Jayakumar T, Liu CH, Wu GY, Lee TY, Manubolu M, Hsieh CY, Yang CH, Sheu JR (2018) Hinokitiol inhibits migration of A549 lung cancer cells via suppression of MMPs and induction of antioxidant enzymes and apoptosis. Int J Mol Sci 19:E939

20. Ikeda R, Nagao T, Okabe H, Nakano Y, Matsunaga H, Katano M, Mori M (1998) Antiproliferative constituents in umbelliferae plants. III. Constituents in the root and the ground part of Anthriscus sylvestris Hoffm. Chem Pharm Bull 46:871-874

21. Karimi M, Conserva F, Mahmoudi S, Bergman J, Wiman KG, Bykov VJ (2010) Extract from Asteraceae brachylaena ramiflora induces apoptosis preferentially in mutant p53-expressing human tumor cells. Carcinogenesis 31:1045-1053

22. Khan N, Hadi N, Afaq F, Syed DN, Kweon MH, Mukhtar H (2007) Pomegranate fruit extract inhibits prosurvival pathways in human A549 lung carcinoma cells and tumor growth in athymic nude mice. Carcinogenesis 28:163-173

23. Way TD, Tsai SJ, Wang CM, Ho CT, Chou CH (2014) Chemical constituents of Rhododendron formosanum show pronounced growth inhibitory effect on non-small-cell lung carcinoma cells. J Agric Food Chem 62:875-884

24. Min HY, Park EJ, Hong JY, Kang YJ, Kim SJ, Chung HJ, Woo ER, Hung TM, Youn UJ, Kim YS, Kang SS, Bae K, Lee SK (2008) Antiproliferative effects of dibenzocyclooctadiene lignans isolated from Schisandra chinensis in human cancer cells. Bioorg Med Chem Lett 18:523-526

25. Davis RA, Barnes EC, Longden J, Avery VM, Healy PC (2009) Isolation, structure elucidation and cytotoxic evaluation of endiandrin $B$ from the Australian rainforest plant Endiandra anthropophagorum. Bioorg Med Chem 17:1387-1392

26. Ou JP, Lin HY, Su KY, Yu SL, Tseng H, Chen CJ, Hsu HC, Chan DC, Sophia Chen YL (2012) Potential therapeutic role of z-isochaihulactone in lung cancer through induction of apoptosis via notch signaling. Evid Based Compl Alt 2012:809204

27. Covarrubias L, Hernandez-Garcia D, Schnabel D, Salas-Vidal E, Sc CastroObregon (2008) Function of reactive oxygen species during animal development: passive or active? Dev Biol 320:1-11

28. Halliwell B (2011) Free radicals and antioxidants-quo vadis? Trends Pharmacol Sci 32:125-130

29. Chakraborty D, Ghosh S, Bishayee K, Mukherjee A, Sikdar S, KhudaBukhsh AR (2013) Antihyperglycemic drug Gymnema sylvestre also shows anticancer potentials in human melanoma A375 cells via reactive oxygen species generation and mitochondria-dependent caspase pathway. Integr Cancer Ther 12:433-441

30. Hsieh CJ, Kuo PL, Hsu YC, Huang YF, Tsai EM, Hsu YL (2014) Arctigenin, a dietary phytoestrogen, induces apoptosis of estrogen receptor-negative breast cancer cells through the ROS/p38 MAPK pathway and epigenetic regulation. Free Radic Biol Med 67:159-170

31. Pan LL, Wang XL, Luo XL, Liu SY, Xu P, Hu JF, Liu XH (2017) Boehmenan, a lignan from the chinese medicinal plant Clematis armandii, inhibits A431 cell growth via blocking p7056/S6 kinase pathway. Integr Cancer Ther 16:351-359

32. Luo J, Kong W, Yang M (2014) HJC, a new arylnaphthalene lignan isolated from Justicia procumbens, causes apoptosis and caspase activation in K562 leukemia cells. J Pharmacol Sci 125:355-363

33. Liu LH, Zhou YJ, Ding L, Zhang SZ, Sun J, Cao JG (2014) Induction of apoptosis by VB1 in breast cancer cells: the role of reactive oxygen species and Bcl-2 family proteins. Int J Mol Med 33:423-430

34. Kuete V, Mbaveng AT, Nono EC, Simo CC, Zeino M, Nkengfack AE, Efferth $\mathrm{T}$ (2016) Cytotoxicity of seven naturally occurring phenolic compounds towards multi-factorial drug-resistant cancer cells. Phytomedicine 23:856-863

\section{Publisher's Note}

Springer Nature remains neutral with regard to jurisdictional claims in published maps and institutional affiliations. 